LJILJANA RADONIĆ, Lecturer

Department of Political Science

University of Vienna

\title{
CROATIAN POLITICS OF THE PAST - JUST ONE MORE POST-COMMUNIST CASE STUDY?
}

\begin{abstract}
Countless publications and conferences on post-communist politics of the past raise the question if comparison of "case studies" can be achieved by mere sequence or if this leads to obliterating particularities. This question is examined on the "case study" of Croatia - looking closely at historical particularities and the role of president Tudman fashioning himself as World War II historian during the 1990s. Generally, three phases of approaching the World War II past can be observed: the revisionist Tudman-era (1990-1999), the social democratic intermezzo, in which democratic transformation was followed by avoidance of demonizing concepts of the enemy (2000-2003), and the new HDZ-governance, when allowanced were made for integration into the EU - while "the Serbs" were depicted as the "new Fascists" of the last war by prime minister Ivo Sanader (2003-2009).
\end{abstract}

Germany - the homeland of national socialism - paradoxically being Europe-wide seen as the role model for approaching one's own felonious past in a critical way, it is not surprising that German historians and cultural scientists have been the ones who have advanced also the theoretical basis for reflecting the relationship between history, memory and national identity. Jan and Aleida Assmann have developed the concept of cultural memory, understood as the "body of reusable texts, images, and rituals specific to each society in each epoch, whose 'cultivation' serves to stabilize and convey that society's self-image."1 Memory theory highlights that individuals and collectives use memory only for present purposes; they remember only those events they can integrate into their picture of themselves or

${ }^{1}$ J. Assmann, "Collective Memory and Cultural Identity", in: New German Critique, No. 65, 1995, 125-133, 132. (Translation of the German version: "Kollektives Gedächtnis und kulturelle Identität", in: J. Assmann/T. Hölscher (ed.), Kultur und Gedächtnis (Frankfurt, 1988), 9-19). 
their in-group. On the national and state level the term "Vergangenheitspolitik", politics of the past, aims at how democratic societies approach their felonious past on the political, judicial and cultural level. ${ }^{2}$

Those theoretical reflections go hand in hand with a vast number of publications dealing with the way the past has been approached in single European countries, often comprised as chapters of edited volumes, thus hoping to achieve a comparative perspective. ${ }^{3}$ Moreover, national case studies on memory and remembrance policies have been presented on numerous international conferences - focusing on post-communist countries in Europe after 1989 or in the most cases comparing them with the development in "western" states. This boom brought along the ability to discuss questions of historical revisionism concerning World War II at conferences in the USA, Great Britain or - when it comes to post-communist transformation- also in "western" Europe - almost as down-to-earth and matter-offactly as issues concerning ancient Rome.

A completely different situation occurs if the same lectures or articles are received by an audience either in the country the "case study" deals with or in the broader area of closely connected but conflicting memories. Scientists usually teaching nationalism or identity theory suddenly insist that this particular case, "our" experience is different, being either especially understandable or especially brutish due to a specific historical constellation. Of course the different assessment depends on the question if one talks about crimes committed by what is considered one's own collective or by the "constituent Other", the everlasting enemy.

This article examines the question of historical particularity vs. general mechanisms of approaching the past when it comes to Croatia's politics of the past from 1990 until $2008^{4}$ - analyzing first of all Croatian newspapers and schoolbooks. Have there been significant changes in this politics and how can they be explained? Keeping in mind the tension between the allegedly academic nature of such research in the course of a "memory boom", which is conflicted by the still raging "war on memory" between the successor states of former Yugoslavia, the Croatian "case study" is conducted from the standpoint of what Volkhard Knigge has called "negative me-

${ }^{2}$ G. Sandner, "Hegemonie und Erinnerung. Zur Konzeption von Geschichts- und Vergangenheitspolitik", in: Österreichische Zeitschrift für Politikwissenschaft 1 (2001), 5-17, 7.

${ }^{3}$ See M. Flacke (ed.), Mythen der Nationen. 1945 - Arena der Erinnerung (Mainz, 2004); B. Faulenbach/F.-J. Jelich (ed.), „Transformationen“ der Erinnerungskulturen in Europa nach 1989 (Essen, 2006); R. Fritz/C. Sachse/E. Wolfrum (ed.), Postdiktatorische Gesellschaften in Europa (Göttingen, 2008).

${ }^{4}$ Lj. Radonić, Krieg um die Erinnerung. Kroatische Vergangenheitspolitik zwischen Revisionismus und europäischen Standards (Frankfurt, 2010). 
mory" ${ }^{\prime 5}$ : the remembrance of acts committed rather than suffered by the collective one is understood to belong to - hoping to advance this self-critical approach rather than to confirm simplifying preconceptions.

Speaking about historical particularities in former Yugoslavia when it comes to World War II, one must mention the civil war between the Partisans, Ustaša and Četnik raging after the partition and occupation of most parts of the country. The Yugoslav antifascist narrative tried to ignore this aspect of the war as well as any ethnically motivated crimes and thus was not able to provide an accurate collective memory for all the marginalized groups. Another aspect little known in Europe when it comes to World War II on the Balkans is who the people were who had been killed and out of what "reasons". In "western" countries after the figure of the not ethnically defined resistance fighter and anti-fascist, the Jews have moved into the focus of World War II memory, but soon the Holocaust was dehistorized by focusing on the individual victim, the memory of the Shoa transformed into an universal imperative to respect human rights in general, a "container" for the memory of different victims. ${ }^{6}$ Thus, only few people outside former Yugoslavia - of course beside the experts in the history of the Balkans - are aware of the fact that beside the Jews and the Roma the Serbs had been the by far largest victim group in the "Independent State of Croatia" (NDH) 1941-1945. Another circumstance little known in European history concerns the role of the Ustaša in the NDH, who just like the Slovaks were given some kind of autonomy by Hitler and Mussolini. But unlike other Central East European countries they started running death camps on their own territory already in summer 1941 - of course inspired by the National Socialists, but operated on their own. While the Romanians run such camps in the newly acquired "killing fields" of Transnistria ${ }^{7}$, the Ustaša chose places in Croatia under their civil administration (but under Italian military command), starting with Jadovno, Gospić as well as Slana and Metajna on Pag.

\section{The Tuđman era}

The historical circumstances described above are essential for understanding the role of the past in Croatia's striving towards independence. Like all the other post-communist countries, a "golden era" of pre-communist

${ }^{5}$ V. Knigge, „Europäische Erinnerungskultur. Identitätspolitik oder kritisch-kommunikative historische Selbstvergewisserung", in: Kulturpolitische Gesellschaft e. V. (ed.), kultur.macht.europa - europa.macht.kultur. Begründungen und Perspektiven europäischer Kulturpolitik (Bonn 2008), 69-82, 157.

${ }^{6}$ D. Levy and N. Sznaider, The Holocaust and Memory in a Global Age (Philadelphia, 2005).

7 See R. Rozett/S. Spector (ed.): Encyclopedia of the Holocaust, http://www.answers.com/topic/domanevka, 5. 5. 2011. 
autonomy seemed to be needed for rewriting history into a new national narrative. But unlike today's Czech Republic, which had a democratic interwar tradition to allude to, the Baltic States, Slovakia and Croatia have chosen the World War II period for this positive reference, defining down collaboration with the Nazis. But at this time, Croatia found herself in a different position than other post-socialist countries, first of all because the new Croatian president fashioned himself a World War II historian and made the (revisionist) politics of the past one of the most important issues on his agenda. From a former partisan and general of the Yugoslav army, from the 1960s onwards Franjo Tuđman had more and more converted to a revisionist historian and an extreme Croatian nationalist who established the practice of stressing anti-fascist values and his own role in the partisan movement while renarrating the Ustaša past as a "milestone to Croatia's independence". Although anti-fascism was formally anchored in the new constitution, it seemed that the idea of a Croatian state was only conceivable in combination with historical revisionism concerning the character of the Ustaša-state. President Franjo Tuđman's anti-Semitic book "Wastelands of Historical Reality" (1989) ${ }^{8}$ equated crimes committed by Ustaša and Partisans by minimizing the number killed in the Ustaša concentration camp Jasenovac, thus taking the first step in establishing a historical narrative for the new state. The second step was Tuđman's idea to reconcile Ustaša and Partisans: According to him they had both fought for the same goal during World War II, albeit in different ways-the Croatian cause. ${ }^{9}$ In connection with this idea, the Jasenovac memorial area played a great symbolic role: referring to the Spanish General Francisco Franco's example, Tuđman suggested bringing the bones of the Ustaša and of soldiers of the NDH ("Domobrani") killed by the partisans near Bleiburg in Mai 1945 to a "national memorial" Jasenovac, ${ }^{10}$ but Tuđman had to drop these plans following international criticism.

The tension between the two lieux de mémoire ${ }^{11}$ Jasenovac and Bleiburg, which were parallelized by calling Bleiburg the site of the "Croatian holocaust" ${ }^{12}$, gives an accurate picture of national victimhood and the denial of responsibility for the Ustaša crimes during the Tuđman era. The

${ }^{8}$ See F. Tuđman, Bespuća povijesne zbiljnosti (Zagreb, 1994).

${ }^{9}$ See M. Čulić, Tuđman: anatomija neprosvijećenog apsolutizma (Split, 1999), 105-108.

${ }^{10}$ See V. Ivančić, Točka na U. Slučaj Šakić (Split, 2000), 132.

${ }^{11}$ In contrast to Nora and François/Schulze in this paper the national lieux de mémoire are not described in an affirmative manner, but are analyzed as mythical sites of "imagined communities". (P. Nora, Zwischen Geschichte und Gedächtnis (Berlin 1990); E. François and H. Schulze, eds., Deutsche Erinnerungsorte (München 2001).

${ }^{12}$ J. I. Prcela and D. Živić, Hrvatski Holokaust. Dokumenti i svjedočanstva o poratnim pokoljima u Jugoslaviji (Zagreb, 2001). 
Bleiburg commemorations under the patronage of the Croatian parliament or government always had many more visitors and were broadcast live on television-despite the Ustaša insignia present throughout the site ${ }^{13}$-while the Jasenovac commemorations have only been broadcast since $2003 .{ }^{14}$ The Catholic Church dispatched bishops to the much better frequented commemorations in Bleiburg, while no Catholic priest had attended a commemoration in Jasenovac during the $1990 \mathrm{~s} .{ }^{15}$ The only Croatian politicians Tuđman sent to attend the commemorations in Jasenovac had been Partisans in their youth, although this was hardly noticeable in their speeches at the site, since they instrumentalized the commemorations to underscore the narrative of Croatian victimhood. ${ }^{16}$ In 1999 for example, General Janko Bobetko spoke about the crimes in Kosovo without even mentioning Jasenovac, followed by the second representative of the President, Slobodan Lang, who spoke about Kosovo and the Homeland War, while the representative of the Parliament, Milivoj Kujundžić, spoke about the "black and the red totalitarianism" and the minister of justice Zvonimir Šeparović mentioned "victims of all crimes, no matter who had committed them." (Novi list, April 26 1999) No one mentioned the perpetrators in Jasenovac, while most of the speeches focused on Serbian crimes.

Contrary to the way lip service was paid to anti-Fascism, most street names, which formerly commemorated the victories of the Partisan struggle and the victims of World War II, were renamed. The best-known and most disputed example is the renaming of the "Square of the Victims of Fascism," the square where the Ustaša police had its headquarter in Zagreb, into the "Square of the Croatian Heroes." Seventeen streets throughout Croatia were named after Mile Budak, a "poet" and the Ustaša Minister of Education, who was responsible for the NDH's racial laws. "Only" cafés and kindergartens were named after the leader of the Ustaša - Ante Pavelić.

According to the "Association of the anti-Fascist fighters" (SAB), from the time Croatia became independent in 1991 until 1998, 2,966 memorials commemorating "victims of Fascism" or the anti-Fascist struggle were removed or destroyed, without anyone being punished for it. ${ }^{17}$ In 1993, a memorial plaque commemorating the "Ustaša fallen for the $\mathrm{NDH}$ " was placed on the building which housed the Croatian army in

${ }^{13}$ Novi list, 12 May 2003.

${ }^{14}$ Novi list, 15 May 2006.

${ }^{15}$ Novi list, 29 April 2002; For an overview of the commemorations in Bleiburg see Slobodna Dalmacija, 12 May 2003.

${ }^{16}$ Novi list, 29 April 2002.

17 J. Hrženjak, Rušenje antifašističkih spomenika u Hrvatskoj 1990-2000 (Zagreb, 2002). 
Sinj. ${ }^{18}$ In 1999, a memorial for the Ustaša criminal Jure Francetić, the founder of the "Black Legion," was erected in Slunj. ${ }^{19}$

History books also reflected the revisionist approach typical of the 1990s. In Yugoslavia half of the school books for the eighth grade of junior high school were dedicated to a discussion of World War II, but this history of World War II only encompassed the Partisan struggle for liberation. ${ }^{20}$ After Croatia became independent, World War II was covered in only one fifth of the new history books for the eighth grade. In these, the Independent State of Croatia was primarily discussed. The NDH was treated as Croatian history, the Croatian wish for an independent state was described, as was the structure of the regime, but its atrocities were hardly mentioned. Jasenovac was mentioned only in two lines and the term Holocaust was not mentioned at all, while Bleiburg and the crimes of the Četniks were described extensively. They also included shocking pictures. Thus, the school books in Croatia presented an equally one-sided picture as those in former Yugoslavia had, though the slant they presented was totally different. ${ }^{21}$

In summary, what happened after Croatia gained its independence was not a "pluralization" of memory, but a total change of contents from the "memory" of the Partisans to a "memory" dominated by returning Ustaša, while the narrative of the past remained Manichean and full of hatred towards "the Serbs", the "Croatian traitors" and the "anti-Croatian foreign circles". Furthermore, the commitment to anti-Fascism in the Constitution remained mere lip service (Hockenos, 2003) and the violation of democratic standards corresponded with the domination of a revisionist historical narrative.

\section{A turnabout in 2000?}

With Tuđman's death in 1999, a decade of HDZ administration ended and a coalition under the leadership of the Social Democratic Prime Minister Ivica Račan, a reformed communist, gained power, while Stipe Mesić, also a former Communist official who first joined the HDZ, but left it again in 1994, was elected president. The authority of the presidential office was diminished soon afterwards. During the process of democratization the manner in which the past was dealt with in Croatia also changed.

Already in 2000 a new school book appeared in which the Holocaust was mentioned, and the number of victims at the Jasenovac concentration

${ }^{18}$ Slobodna Dalmacija, 16 September 2004.

${ }^{19}$ Čulić, Tuđman, 106.

${ }^{20}$ See e.g. S. Perazić, Udžbenik za 8. razred osnovne škole (Sarajevo, 1973).

${ }^{21}$ I. Perić, Povijest 8: udžbenik za 8. razred osnovne škole (Zagreb, 1992); H. Matković, Povijest 8: udžbenik za 8. razred osnovne škole (Zagreb, 1998). 
camp was given. The book claimed that 80,000 victims had perished there, which is quite an accurate figure, since current research estimate a number of $80,000-100,000$ victims. Furthermore, Jasenovac was truthfully described as an extermination camp. However, since the author of this book was Hrvoje Matković, who also wrote the previous school book in 1998, the tone did not change in general. ${ }^{22}$ In 2003 , a much more accurate school book, which discussed the Holocaust and the Nazi death camps, was published, but it was not widely accepted-only a few schools used it. ${ }^{23}$

In December 2000 the "Square of the Victims of Fascism" received its old name back and Tuđman's reburial-plans for a "national memorial" Jasenovac were finally shelved. In contrast to the 1990s, when only representatives of different national, religious and political organizations spoke at the commemorations in Jasenovac, in 2002 Ivica Račan was the first acting Prime Minister who spoke there. ${ }^{24}$ However, he balked from clearly stating who had committed the crimes during the Ustaša-regime. Instead he spoke generally about the evil that had happened in Jasenovac, without naming those responsible for the atrocities. Thus, a change of the hegemonic narrative could be observed, but it seems that the former Communist Račan was unwilling or afraid to come fully to terms with the revisionist Tuđman-era. The ambivalent perspective of the Račan-government was also reflected in some of its members visiting Bleiburg, despite the Ustaša-iconography which dominated the commemoration year after year. Račan also went to Bleiburg, but he apologized for the crimes committed by the partisans apart from the annual commemoration.

When President Stipe Mesić on the other hand was asked whether he planned to visit Bleiburg in 2005, he answered: "We are not comparing Bleiburg and Jasenovac. None of the victims from Jasenovac were responsible for the people killed in the trenches and in Bleiburg, but a lot of people in Bleiburg were responsible for mass murder. They are victims, but we cannot say they are innocent. They should not have been killed and tormented, but they should have been put on trial." ${ }^{25}$ As President, Mesić always found clear words about the Ustaša crimes at the commemorations in Jasenovac and at other occasions. He condemned the idea of the "reconciliation of all Croats" 26 as a falsification of history and also condemned the crimes committed in the name of the Croatian state, including not only the ones in the Jasenovac death camp, but also those from the more recent past, just as he

${ }^{22}$ H. Matković, Povijest 8: udžbenik za 8. razred osnovne škole (Zagreb, 2000).

${ }^{23}$ M. Kolar Dimitrijević, Povijest 8: udžbenik za 8. razred osnovne škole (Zagreb, 2003).

\footnotetext{
${ }^{24}$ See Novi list, 20 April 2002.

${ }^{25}$ Novi list, 23 April 2005.

${ }^{26}$ Novi list, 12 May 2003.
} 
supported the conviction of the old as well as of the more recent war criminals.

To sum up, after Tuđman's death democratization went hand in hand with the apparent end of the Manichean distinction between the anti-Croatian evil on the one hand and the sacred nation on the other. President Mesić managed to establish a democratic, anti-fascist narrative, while Premier Račan tried to maintain a balance between the nationalist heritage of the Tuđman-era and his leftist supporters. Although some representatives of the parliament again called Bleiburg the site of the "Croatian holocaust", this became only one of many versions of the past opined in public.

\section{The new HDZ - returning revisionism or orientation towards Europe?}

In 2003, the HDZ won the elections again. Prime Minister Ivo Sanader was known as a Europe-oriented statesman who broke with the revisionist ideas of his predecessor. The Sanader-administration removed the memorials for the Ustaša authorities Mile Budak in Sveti Rok and Jure Francetić in Slunj and started an initiative to rename the aforementioned 17 streets throughout Croatia that carried the name of Mile Budak. During the Jasenovac commemoration in 2004 Sanader demanded: "We must not allow for the atrocities that occurred in Jasenovac and elsewhere during the Ustaša regime in the NDH (Independent State of Croatia) to be forgotten." ${ }^{27}$ He was the first HDZ politician in Jasenovac who broke with the tradition of mentioning the victims of Bleiburg alongside those killed in Jasenovac and explicitly called the Ustaša regime responsible for Jasenovac ${ }^{28}$ - while Tuđman and his followers had spoken of some kind of ontological evil that had led to the atrocities. However, critical media expressed their skepticism, when HDZ politicians like Andrija Hebrang and Vladimir Šeks, in diametric opposition to their prior appearances, began delivering anti-Fascist speeches. ${ }^{29}$ Excluding Sanader and his inner circle, the positions of the HDZ did not seem to have changed decisively, although the perspective of joining the European Union forced the party to at least officially temper its mood.

"The Serbs" played, and continue to play an enormous role in the narrative of the Croatian "imagined community" ${ }^{30}$ and today's political

27 http://www.vlada.hr/default.asp?ru=345\&gl=200403160000006\&sid=\&jezik=2 (6 March 2007).

${ }^{28}$ Feral Tribune, 18 March 2004; Novi list, 17 March 2004.

${ }^{29}$ Feral Tribune, 29 April 2004.

${ }^{30}$ B. Anderson, Imagined Communities: Reflections on the Origin and Spread of $\mathrm{Na}$ tionalism (London, 1991). 
conflicts almost always refer to conflicting "memories." In 2005, before the commemoration in Jasenovac, there was also a commemoration at the memorial site in Donja Gradina (Republika Srpska, Bosnia and Herzegovina), which used to be part of the Jasenovac memorial area. On this occasion, the President of the Republika Srpska, Dragan Čavić, stated that there is still no justice for the 700,000 victims of Jasenovac. Afterwards, at the round table on "Tendencies of Historiography and Research on the Jasenovac Concentration Camp" in Banja Luka, the anthropologist Srboljub Živanović from London made the dubious statement that Croatia still has not overcome its "genocidality," although Croatian politicians, who "reduce" the figures to 70,000 , claim the opposite. ${ }^{31}$

Sanader, Croatian Prime Minister until 2009, responded to the "provocation" from the commemoration at the other bank of the Sava river. He condemned "the positions of Greater Serbia in imposing the theory of the alleged genocidal tendencies of the Croatian people" and the exaggeration, but also the reduction of the number of victims. The Premier emphasized contemporary Croatia's "commitment to anti-Fascist values," ${ }^{32}$ but he added that the "Homeland War" (1991-1995) was also fought against one type of Fascism. He argued similarly in Yad Vashem (!) in 2005, when he pointed out that in the war in the 1990s, the Croats were also victims of the same kind of evil as Nazism and Fascism, and that no one knew better than the Croats what it meant to be a victim of aggression and crime. ${ }^{33}$ The Holocaust History Museum further inspired Sanader to think about a Museum of the Homeland War, as he told journalists after his visit. ${ }^{34}$ This shift away from historical revisionism, which minimized the victims of the Ustaša state in the Tuđman-era, to a new view that recognizes the Holocaust, but on the other hand presents the Croats as victims of Fascism, this time of "Serbian Fascism" shows the problematic nature of the "globalization of the Holocaust." 35 Thus, Levy and Sznaider are obviously right when they argue that the Holocaust is more and more becoming a "container" for the memory of different victims, but this development obviously cannot be diagnosed as neutrally as the authors suggest.

Furthermore, although the HDZ politicians do not mention the "Croatian suffering" near Bleiburg during the annually commemorations in Jasenovac any more, Sanader and his colleagues keep condemning "both

\footnotetext{
(6 March 2007).

${ }^{33}$ http://www.vlada.hr/default.asp?gl=200506280000018 (6 March 2007).

${ }^{34}$ See Vjesnik, 29 June 2005.

${ }^{35}$ Levy/Sznaider. The Holocaust.
}

${ }^{31}$ Novi list, 18 April 2005.

32 http://www.vlada.hr/default.asp?ru=345\&gl=200505020000004\&sid=\&jezik=2 
totalitarianisms", the "red and the black one" ${ }^{36}$. This formulation obviously corresponds with European standards perfectly, since totalitarianism is even mentioned in a short Sanader quotation in the Ten year anniversary book of the ITF: „Democracy's victory over totalitarianism is the victory of the values embedded in modern Europe and modern Croatia. ${ }^{.37}$

The most striking example of problematic aspects of the "Europeanization of Memory" -implementing the Holocaust as a dehistorized moral imperative - is yet the new exhibition at the state-funded Jasenovac Memorial Museum, which after long debates opened at the end of 2006. The main progress of the new exhibition seems to be the acknowledgment of the fact that the Shoa had happened in Croatia. At the same time it is stressed that the extermination of the Croatian Jews must be seen in the broader context of the Holocaust, while the fact is not mentioned that most collaborating regimes did not operate death camps on their own like the Ustaša did. It is this emphasis on the Holocaust, which corresponds with international standards of commemorating and exhibiting World War II that makes the problematic of a dehistorized identity-creating memory so obvious: While focusing on the Holocaust, the genocide against the Serbs (by far the largest victim group) and the Roma is marginalized.

The director, Nataša Jovičić, defended the exhibition by saying that it had been conceptualized together with international experts because she wanted it to be "internationally recognizable and in the context of international standards". ${ }^{38}$ Yet these experts only came from institutions concerned with the Holocaust like the US Holocaust memorial museum, the AnneFrank-House or Yad Vashem. The Croatian curators did not orient themselves on memorial museums at the sites of former concentration camps in Germany or the Generalgouvernement, which try to show the complex character and daily routine of a KZ, but on other institutions: "Like at the Anne Frank House" Jovičić wants to "tell a tragic life story with the help of a few objects". ${ }^{39}$ Of course it is understandable that the current focus on individual victim stories is dominant at the Anne-Frank-House. But in Jasenovac a hypermodern exhibition also uses new media in order to spotlight only single victim stories, as it is described in an article in the state-owned daily Vjesnik: "Even more thoroughly than the Holocaust Memorial Museum in Washington and the Anne Frank House in the Netherlands the director

${ }^{36}$ See Vjesnik, 17 March 2004, 26 April 2004, 28 November 2006 and 21 April 2008.

37 Task Force for International Cooperation on Holocaust Education, Remembrance and Research, Ten year anniversary book, (Stockholm, 2009), 32.

${ }^{38}$ Vjesnik, 14 February 2004.

${ }^{39}$ Vjesnik, 24 Mai 2004. 
of the Jasenovac Memorial, the art historian Nataša Jovičić, decided to devote the whole new museum exhibition (in preparation) to the victims". ${ }^{40}$ Referring directly to the "illustration of the executioner and the victim in world museology", the concept planned not to show anonymous death bodies and killing weapons as it was done before, but to make Jasenovac a "site of life" and of an affirmative message. Thus, the legitimate critic of the shock-aesthetic on the one hand is bond together with trying to make sense out of the events by "sending a message of light to the site of crime" on the other hand. ${ }^{41}$

However, critics also faulted the new exhibition concept for not showing who the perpetrators were, which nation had the biggest losses and how people were killed in Jasenovac - the "manufacture of death", as it is called by some scholars. ${ }^{42}$ After a long debate, some brute killing instruments, knives and mallets, were added to the exhibition as well as the nationality and age of the victims in order to show that not only political prisoners were killed there, as it was often claimed during the 1990ies. International experts seem to have welcomed the exhibition's concept maybe as enthusiastically as Jovičić stressed it numerous times. ${ }^{43}$ Thus, one can either reason that most problems of the primal concept of the exhibition have been solved - and many important issues were - or that the "universalization of the holocaust" aims only at a symbolic acknowledgment of the Shoa in order to open future perspectives of a global human rights discourse. However, what Reinhart Kosellek stressed for Germany stands also for Croatia: both cannot only commemorate the victims, but must also or even first of all remember the perpetrators. ${ }^{44}$ In the Croatian case there cannot be an exhibition (supported by international experts and meeting international aesthetic standards) concentrating on the (Jewish) victims in a country and a region where the engagement with one's own crimes, "negative memory", has not yet come very far.

\section{Conclusion}

The fact that an Europe-oriented Croatian politics of the past first of all of the former prime minister Ivo Sanader depicted Croats as the new Jews and the Serbs as the new Fascists during the war in the 1990s and re-

${ }^{40}$ Vjesnik, 7 March 2004.

${ }^{41}$ Vjesnik, 7 March 2004.

${ }^{42}$ See Novi list, 24 January 2006 and 29 January 2006.

${ }^{43}$ See Vjesnik, 24 Mai 2004.

${ }^{44}$ See R. Koselleck, „Formen und Traditionen des negativen Gedächtnisses,“ in: V. Knigge/N. Frei, Verbrechen erinnern. Die Auseinandersetzung mit Holocaust und Völkermord (München, 2002). 
mained undisputed by the "international community" on Croatia's way into the EU on the one hand tells us something about the problematic nature of the "Europeanization of Memory", in which the Holocaust has become a moral imperative to protect human rights and identify with the individual victim without referring to Jews as the victims and the Germans and their collaborators as the perpetrators any more. On the other hand this tell us something about the current state of the "war on memory" in former Yugoslavia: While during the 1990s the "Croatian holocaust" in Bleiburg and the "serbo-communist" villains had been at the center of the Croatian victim narrative, after 2003 the focus has shifted to acknowledging and condemning the Ustaša crimes (though in an dehistorized, merely symbolic way, as the Jasenovac Memorial Museum shows), but depicting Serbs as the absolute evil during the wars of the 1990s. Thus, while World War II is becoming "cold" memory at least partially, the same identification, friend or foe, is applied when it comes to the last war - bringing along the taboo of dealing with ones own role again.

After Sanaders resignation in 2009, his successor Jadranka Kosor continued condemning Ustaša crimes at the commemorations in Jasenovac, but this time without referring to any Serbian perpetrators. Also the new Croatian president, Ivo Josipović, seems to follow his forerunners tradition of stressing the need to approach the past self-critically. At least this is indicated by the fact that he inaugurated a replica memorial plaque at the site of the former concentration camp Jadovno in June 2010, which had been destroyed earlier. On the other hand, Josipović was the first Croatian president who had visited Bleiburg only a few days earlier, what Mesić would never have done. It has to be observed carefully which kind of reconciliation he will try to achieve in the future.

Anyhow, keeping in mind the civil war and the death camps in which Serbs had been by far the largest group of victims as well as that the atrocities of the Ustaša have not been extenuated only by some radical groups or parties like in Slovakia, but by the president himself during the 1990s, brings us to the following conclusion: The mechanisms how the past was dealt with in post-communist countries after 1989 are the same: renarration of history in search of a "golden era" of national independence and bloom, belittlement of collaboration with Nazis and Fascist, focus on "our victims" or the state as a whole being a vulnerable victim's body, demonization of the "constituent Other" as an ontological enemy. Still, the historical circumstances and specifics of collaboration, mass murder and the way this was dealt with after 1989 threat to blur in superficial comparison by sequence of "case studies". Instead the focus should lie on the relation between valid universalization and indispensable particularities as well as on the 
interlinking of conflicting national memories. Thus, how the Croatian side of the "war on memory" corresponds with the depiction of Croats and the celebration of Četniks as anti-fascist in Serbian society is a question yet to be examined in-depth, but a core issue for the Serbian academia - if we stick to the dictum that "negative memory" is the kind of approach to the past we need.

Ljiljana Radonić

\section{HRVATSKA POLITIKA PROŠLOSTI - SAMO JOŠ JEDAN PRIMER POSTKOMUNISTIČKE STUDIJE SLUČAJA?}

\section{Rezime}

Bezbrojne publikacije i konferencije o „politici prošlosti“ postkomunističkih država pokazuju da komparativna perspektiva koja se sastoji samo od nizanja studija slučaja raznih država gubi iz vida pitanje odnosa potrebne generalizacije i neporecivih posebnosti. Članak se iz toga razloga bavi pitanjem koliko je u slučaju Hrvatske reč o mehanizmima suočavanja sa prošlošću koji se mogu posmatrati u svim postkomunističkim državama. Može se zaključiti da su „izmišljanje“ novog istorijskog narativa, potraga za zlatnom erom državne prošlosti i fokus na "naše žrtve" generalno konstitutivni elementi postkomunističke transformacije politike prošlosti. Pri tome se, međutim, ne smeju izgubiti iz vida istorijske posebnosti, pre svega građanski rat između ustaša, četnika i partizana kao i činjenica da su ustaše bile redak slučaj kolaboracionističkog režima koji je - osim nacista - uspostavio logore smrti i to, za razliku od Rumuna u Transnistriji (Pridnjestrovlju), na vlastitoj teritoriji. U tim ustaškim logorima su pored Jevreja i Roma, Srbi bili daleko najveća grupa žrtava.

Analiza hrvatske politike prošlosti služi se konceptom „negativnog sećanja“, znači istražuje odnos prema zločinima koje je počinio a ne pretrpeo "vlastiti“ kolektiv radi ubeđenja da jedino samokritična analiza vodi do kraja "rata sećanja“ na postjugoslovenskim prostorima. Rezultat su tri faze hrvatske politike prošlosti - era revizionizma predsednika Franje Tuđmana (1990-1999), socijaldemokratski međučin demokratske transformacije i izbegavanja demonizacije ontoloških neprijatelja (2000-2003) i ponovna HDZ-ova vlada koju karakterišu ustupci prema Evropskoj uniji kada je Drugi svetski rat u pitanju, dok je premijer Ivo Sanader u isto vreme Srbe nazivao „novim fašistima“ u poslednjem ratu (2003-2009). 